\title{
HUBUNGAN PENGETAHUAN TENTANG HIV/AIDS DENGAN SIKAP DAN TINDAKAN PENGGUNAAN KONDOM PADA WANITA PEKERJA SEKS DI WILAYAH LOKALISASI KM 12 PALANGKARAYA TAHUN 2013 \\ Oleh :
}

Fransisca Diana Alexandra, Fatmaria, Angeline Novia Toemon

\begin{abstract}
Abstrak
HIV/AIDS merupakan penyakit dengan angka kejadian yang terus meningkat di Indonesia. Epidemi HIV/AIDS terjadi hampir di seluruh provinsi di Indonesia. Salah satu cara pencegahan HIV adalah dengan menggunakan kondom saat berhubungan seksual dengan pasangan berisiko (Riskesdas, 2010 :280). Berdasarkan data riskesdas tahun 2010, prevalensi nasional penduduk yang mengetahui cara pencegahan yang benar bahwa HIV dapat dicegah salah satunya dengan menggunakan kondom saat berhubungan seksual dengan pasangan berisiko adalah sebesar 41,9\% dimana Kalimantan Tengah memiliki persentase sebesar 36,7\% (penduduk usia 15 tahun ke atas) (Riskesdas, 2010:7,282). Penelitian ini bertujuan untuk mengetahui apakah terdapat hubungan pengetahuan tentang HIV/AIDS dengan sikap dan tindakan penggunaan kondom pada wanita pekerja seks di wilayah lokalisasi km 12 Palangka Raya. Penelitian ini merupakan penelitian yang bersifat survey analitik dengan pendekatan cross sectional. Teknik pengumpulan data secara wawancara menggunakan instrumen kuesioner. Kuesioner terdiri dari tiga bagian yaitu penilaian pengetahuan responden mengenai HIV/AIDS dan kondom, penilaian sikap responden dalam mencegah HIV/AIDS dengan penggunaan kondom dan penilaian tindakan responden dalam penggunaan kondom. Populasi penelitian ini adalah para wanita pekerja seks di lokalisasi km 12 Palangka Raya sebanyak 140 orang. Sampel penelitian ini berjumlah 65 orang yang dipilih dengan pendekatan acak sederhana namun mengalami drop out sebanyak 5 orang sehingga jumlah responden menjadi 60 orang. Data hasil penelitian dianalisis dengan menggunakan software SPSS for windows versi 11.5 dan menggunakan metode analisis univariat dan bivariat. Hasil analisis penelitian menunjukkan ada hubungan yang bermakna antara pengetahuan responden tentang HIV/AIDS dan kondom terhadap sikap dan tindakan responden dalam penggunaan kondom (chi-square hitung > chi-square tabel).
\end{abstract}

kata kunci: pengetahuan, sikap, tindakan, wanita pekerja seks, HIV/AIDS, penggunaan kondom

\section{A. Pendahuluan}

Salah satu dari delapan strategi pembangunan milenium semesta (Millennium Development Goals; MDGs) mengisyaratkan semua negara di dunia untuk memerangi penularan HIV/AIDS. Pada tahun 2008 di seluruh dunia jumlah orang yang hidup dengan HIV/AIDS terus meningkat dan diperkirakan telah mencapai angka 33,4 juta jiwa. Jumlah ini lebih banyak 20\% dibandingkan data pada tahun 2000 dan angka prevalensinya telah meningkat tiga kali lipat sejak tahun 1990 (UNAIDS, 2009).

Di Indonesia, HIV/AIDS yang merupakan new emerging diseases telah menjadi pandemi di semua kawasan (Depkes, 2001). Penyakit ini beberapa tahun terakhir menunjukkan kejadian peningkatan yang mengkhawatirkan sampai dengan tahun 2009 jumlah kumulatif kasus AIDS yang dilaporkan mencapai angka 19.973 kasus dan tersebar di 32 provinsi di Indonesia. Selain peningkatan jumlah kumulatif, jumlah kasus baru HIV/AIDS yang dilaporkan juga terus meningkat. Pada tahun 2008 jumlah kasus baru yang dilaporkan adalah 4.969 orang meningkat dua kali lipat dibandingkan tahun 2006 sebesar 2.873 orang (Spiritia, 2009).

Berdasarkan data riskesdas tahun 2007, prevalensi nasional pernah mendengar HIV/AIDS adalah 44,4\%. Sebanyak 17 provinsi mempunyai prevalensi pernah mendengar HIV/AIDS dibawah prevalensi nasional salah satunya adalah Kalimantan Tengah dengan 
persentase 40,5\% (penduduk usia 10 tahun ke atas). Prevalensi nasional berpengetahuan benar tentang penularan HIV/AIDS (diantara penduduk yang pernah mendengar HIV/AIDS) adalah 13,9\%. Sebanyak 16 provinsi mempunyai prevalensi berpengetahuan benar tentang penularan HIV/AIDS (diantara penduduk yang pernah mendengar HIV/AIDS) dibawah prevalensi nasional salah satunya adalah Kalimantan Tengah dengan persentase 10,9\% (penduduk usia 10 tahun ke atas) (Riskesdas, 2007:200). Menurut riskesdas tahun 2010, prevalensi nasional penduduk yang mengetahui cara pencegahan yang benar bahwa HIV dapat dicegah salah satunya dengan menggunakan kondom saat berhubungan seksual dengan pasangan berisiko adalah sebesar 41,9\% dimana Kalimantan Tengah memiliki persentase sebesar 36,7\% (penduduk usia 15 tahun ke atas) (Riskesdas, 2010:7,282).

Kementerian Kesehatan juga mencatat beberapa faktor penyebab AIDS, yaitu: heteroseksual (53\%), homo-biseksual (3\%), injecting drug user (IDU) (38\%), dan transmisi perinatal (3\%) (Ditjen PPM \& PL Kemkes RI, 2011). Faktor yang menyebabkan kasus HIV/AIDS terus melonjak, disebabkan karena adanya perilaku menyimpang dari perilaku wanita pekerja seks (WPS), homoseks, dan pengguna narkoba suntik yang saling bergantian. Berdasarkan data dari Dinas Sosial Kalimantan Tengah tahun 2013, jumlah wanita pekerja seks di kota Palangka Raya adalah 239 orang dan penderita HIV/AIDS 20 orang (Kaltengpos, 2013). Salah satu upaya yang dapat dilakukan untuk mencegah penularan penyakit HIV/AIDS adalah melalui penggunaan kondom. Negara Thailand tercatat berhasil menurunkan tingkat penularan HIV sampai $83 \%$ dengan program penyediaan kondom. Berdasarkan penelitian yang dilakukan oleh Ridayanti terhadap 31 waria di Medan, hanya 1 waria yang selalu menggunakan kondom dalam aktivitas seksualnya. Demikian juga dengan hasil penelitian yang dilakukan oleh Rumaseuw terhadap wanita penjaja seks di Kabupaten Wamena Irian Jaya, tidak seorangpun wanita pekerja seks yang menggunakan kondom dalam melayani pelanggannya. Hal ini menunjukkan bahwa penggunaan kondom belum dilakukan sebagaimana yang diharapkan untuk mencegah menularnya penyakit HIV/AIDS (Kenderweis, 2010:22). Untuk itu dilakukan penelitian mengenai hubungan pengetahuan tentang HIV/AIDS dengan sikap dan tindakan penggunaan kondom pada wanita pekerja seks di wilayah lokalisasi km 12 Palangka Raya.

\section{B. Tinjauan Pustaka \\ 1. HIV/AIDS \\ 1.1 Definisi}

HIV adalah singkatan Human Immunodefisiency Virus yaitu virus yang menyerang sistem kekebalan tubuh manusia sehingga membuat tubuh rentan terhadap berbagai penyakit. AIDS adalah singkatan Acquired Immune Deficiency Syndrome yaitu suatu penyakit retrovirus yang disebabkan oleh HIV dan ditandai dengan imunosupresi berat yang menimbulkan infeksi opportunistik, neoplasma sekunder dan manifestasi neurologis. HIV telah ditetapkan sebagai agens penyebab Acquired Immune Deficiency Syndrome (AIDS). AIDS adalah suatu kumpulan kondisi klinis tertentu yang merupakan hasil akhir dari infeksi oleh HIV. Apabila jumlah CD4 kurang dari 200 sebagai kriteria ambang batas maka dikategorikan AIDS dimana sel CD4 adalah bagian dari limfosit dan satu target sel dari infeksi HIV ( Price, 2006).

\subsection{Etiologi}

Penyebab AIDS adalah sejenis virus yang tergolong retrovirus yang disebut HIV. HIV merupakan retrovirus RNA. Dalam bentuk aslinya merupakan partikel yang inert, tidak dapat berkembang atau melukai sampai masuk ke sel target. Sel target virus ini terutama sel limfosit T karena sel ini mempunyai reseptor untuk virus HIV yaitu sel CD4. Didalam sel limfosit T, virus dapat berkembang dan tetap hidup lama dalam sel dengan keadaan inaktif. Walaupun 
demikian virus dalam tubuh pengidap HIV selalu dianggap infectious yang setiap saat dapat aktif dan dapat ditularkan selama hidup penderita tersebut. Virus HIV hidup dalam darah, saliva, semen, air mata dan mudah mati diluar tubuh. HIV dapat juga ditemukan dalam sel monosit, makrofag dan sel glia jaringan (Siregar, 2004).

\subsection{Cara Penularan HIV/AIDS}

Virus HIV menyerang sel limfosit $\mathrm{T}$ dan sel otak sebagai organ sasarannya. Virus HIV sangat lemah dan mudah mati diluar tubuh. Vehikulum yang dapat membawa virus HIV keluar tubuh dan menularkan kepada orang lain adalah berbagai cairan tubuh. Cairan tubuh yang dapat menularkan diantaranya semen, cairan vagina atau servik dan darah penderita. Adapun cara penularan HIV adalah melalui :

1. Transmisi seksual

Penularan melalui hubungan seksual baik homoseksual maupun heteroseksual merupakan penularan infeksi HIV yang paling sering terjadi. Penularan ini berhubungan dengan semen dan cairan vagina. Infeksi dapat ditularkan dari setiap pengidap infeksi HIV kepada pasangan seksnya. Resiko penularan HIV tergantung pada pemilihan pasangan seks, jumlah pasangan seks dan jenis hubungan seks. Orang yang sering berhubungan seksual dengan berganti pasangan merupakan kelompok manusia yang berisiko tinggi terinfeksi virus HIV.

2. Transmisi non seksual

- Transmisi parenteral

Terjadi akibat penggunaan jarum suntik dan alat tusuk lainnya yang telah terkontaminasi.

- Produk darah

Penularan melalui donor darah dimana darah mengandung virus HIV.

3. Transmisi Transplasental

Penularan dari ibu yang mengandung HIV positif ke anak. Penularan dapat terjadi sewaktu hamil, melahirkan dan sewaktu menyusui (Siregar, 2004).

\subsection{Pencegahan HIV/AIDS}

Cara pencegahan HIV antara lain sebagai berikut: berhubungan seksual hanya dengan satu pasangan tetap yang tidak berisiko, berhubungan Seksual dengan suami/istri saja, tidak melakukan hubungan seksual sama sekali, menggunakan kondom saat berhubungan seksual dengan pasangan berisiko, tidak menggunakan jarum suntik bersama, melakukan sunat/sirkumsisi (Riskesdas, $2010: 280$ ).

\subsection{Tanda dan Gejala HIV/AIDS}

1. Adanya HIV dalam tubuh orang tidak akan tampak dari penampilan luar. Orang terinfeksi HIV tidak akan menunjukkan gejala apapun dalam jangka waktu yang relative lama (7-10 tahun)

2. Tanda dan gejala AIDS :

a. Gejala mayor

o Berat badan menurun lebih dari $10 \%$ dalam waktu singkat.

o Demam berkepanjangan selama lebih dari satu bulan.

o Diare berkepanjangan lebih dari satu bulan.

b. Gejala minor

o Batuk berkepanjangan selama lebih dari satu bulan

o Kelainan kulit dan iritasi

o Herpes simplek yang menyebar dan bertambah parah

o Infeksi jamur pada mulut dan kerongkongan 
o Pembengkakan kelenjar getah bening diseluruh tubuh yang teraba dibawah telinga, leher, ketiak dan lipat paha. (Siregar, 2004).

\section{Kondom}

\subsection{Definisi}

Menurut sejarah kondom sudah diketahui sejak jaman Mesir Kuno dan dibuat dari kulit atau usus binatang. Atas perintah raja Charles II Inggris, dokter Condom membuat kondom dari kulit binatang dengan panjang $190 \mathrm{~mm}$, diameter $60 \mathrm{~mm}$, dan tebal 0,038 mm. Teknik dan biaya pembuatannya cukup mahal dan keberhasilannya masih rendah sebagai alat kontrasepsi. Dokter Fallopio dari Italia membuat kondom dari linen dengan tujuan utama untuk menghindari infeksi hubungan seks tahun 1564. Dokter Hercule Saxonia pada tahun 1597 membuat kondom dari kulit binatang yang bila hendak dipakai direndam dulu. Kondom terbuat dari karet dikembangkan oleh dokter Hancock pada tahun 1944 dan Goodyer 1970 (Manuaba, 2010).

Kondom merupakan selubung atau sarung karet yang dapat terbuat dari berbagai bahan diantaranya lateks (karet), plastik (vinil) atau bahan alami (produksi hewani) yang dipasang pada penis saat berhubungan seksual. Kondom terbuat dari karet sintesis yang tipis, berbentuk silinder, dengan muaranya berpinggir tebal, yang bila digulung berbentuk rata atau mempunyai bentuk seperti puting susu, berbagai bahan telah ditambahkan pada kondom baik untuk meningkatkan efektifitasnya (misalnya penambahan spermisida) maupun sebagai aksesoris aktifitas seksual (Syaifudin, 2003). Kondom merupakan salah satu alat kontrasepsi pria yang paling mudah dipakai dan diperoleh baik di apotik maupun di toko-toko obat dengan berbagai merek dagang (BKKBN, 2005).

\subsection{Fungsi Kondom}

Kondom mempunyai tiga fungsi yaitu :

a. Sebagai alat KB

b. Mencegah penularan PMS termasuk HIV/AIDS

c. Membantu pria atau suami yang mengalami ejakulasi dini (BKKBN,2005).

\subsection{Kelebihan Kondom}

Kelebihan kondom antara lain : efektif sebagai alat kontrasepsi bila dipakai dengan baik dan benar, murah dan mudah didapat tanpa resep dokter, praktis dan dapat dipakai sendiri, tidak ada efek hormonal, dapat mencegah kemungkinan penularan penyakit menular seksual (PMS) termasuk HIV/AIDS antara suami-isteri, mudah dibawa (BKKBN,2005).

\subsection{Penggunaan Kondom}

a. Bila hubungan seksual dilakukan pada saat isteri sedang dalam masa subur

b. Bila isteri tidak cocok dengan semua jenis alat/metode kontrasepsi

c. Setelah vasektomi, kondom perlu dipakai sampai 15 kali ejakulasi

d. Sementara menunggu penggunaan metode/alat kontrasepsi lain

e. Bagi semua yang isterinya calon peserta pil $\mathrm{KB}$ sedang menunggu haid

f. Apabila lupa minum pil KB dalam jangka waktu lebih dari 36 jam

g. Apabila salah satu dari pasangan suami-isteri menderita penyakit menular seksual termasuk HIV/AIDS

h. Dalam keadaan tidak ada kontrasepsi lain yang tersedia atau yang dipakai pasangan suami-isteri

i. Sementara menunggu pencabutan implant/susuk KB/alat kontrasepsi bawah kulit, bila batas waktu pemakaian implant sudah habis (BKKBN,2005). 


\subsection{Efektivitas Kondom}

a. Kondom efektif sebagai kontrasepsi bila dipakai dengan baik dan benar

b. Angka kegagalan teoritis 3\%, praktis 5-20\%

c. Sangat efektif jika digunakan pada waktu isteri dalam periode menyusui, akan lebih efektif (BKKBN,2005).

\subsection{Cara Penggunaan kondom yang benar}

a. Perhatikan tanggal kadaluwarsa, bila telah kadaluwarsa jangan digunakan.

b. Buka dengan hati-hati dari bungkusnya.

c. Tekan ujung kondom dengan 2 jari

d. Setelah alat kelamin laki-laki menegang pasangkan kondom pada ujung alat kelamin dan lepaskan gulungannya ke pangkal.

e. Lepas kondom setelah ejakulasi dengan hati-hati agar cairan sperma tidak tumpah.

f. Bungkus kondom setelah dipakai lalu dibuang ditempat sampah.

g. Jangan menggunakan pelumas bahan dari minyak, misalnya hand body, lotion, dll. Bahan ini dapat merusak kondom sebaiknya gunakan pelumas dengan bahan cair. (BKKBN,2005)

\section{Penelitian mengenai hubungan antara pengetahuan tentang HIV/AIDS dengan sikap dan tindakan penggunaan kondom.}

\subsection{Penelitian yang dilakukan oleh kenderweis mengenai tingkat pengetahuan pekerja seks} komersial di kabupaten langkat Sumatera Utara

Dalam hal ini merupakan segala sesuatu yang diketahui responden tentang kondom maupun HIV/AIDS. Hasil penelitian menunjukkan hanya 24\% dari 104 responden yang pengetahuannya tentang HIV/AIDS dalam kategori baik dan sebanyak 59,6\% dalam kategori buruk. Sejumlah $29,8 \%$ responden menyatakan setuju terhadap pernyataan berhubungan seks dengan bukan pasangan resmi sebaiknya memakai kondom supaya tidak tertular HIV/AIDS dan penyakit menular seksual lainnya, 30,8\% menyatakan setuju bahwa pelanggan yang dilayani harus menggunakan kondom, 19,2\% menyatakan setuju bahwa pelanggannya dipaksa menggunakan kondom karena telah mengetahui kegunaan kondom, 8,7\% responden yang tidak akan melayani pelanggannya jika pelanggan tersebut menolak menggunakan kondom, dan 31,7\% responden menyatakan merasa lebih aman jika menggunakan kondom (Kenderweis, 2010:24).

\section{a. Faktor pengetahuan}

Hasil penelitian membuktikan bahwa pengetahuan PSK berpengaruh terhadap kemampuan tawar penggunaan kondom oleh PSK kepada pelanggannya. Pekerja Seks Komersial (PSK) yang beroperasi di Kabupaten Langkat belum memahami secara baik tentang kondom dan manfaatnya; hanya 17,3\% yang mengatakan bahwa kondom dapat mengurangi risiko penularan HIV/AIDS. Hal ini berarti informasi tentang pentingnya kondom untuk mencegah terjadinya penularan HIV/AIDS belum tersosialisasi dengan baik. Peningkatan pengetahuan PSK tentang kondom terutama terkait dengan fungsinya sebagai pencegah penularan penyakit HIV/AIDS diproyeksikan dapat meningkatkan kemampuan tawar penggunaan kondom kepada pelanggannya. Oleh karena itu penguatan kapasitas PSK melalui pembelajaran dengan berbagai bentuk perlu lebih banyak dilakukan, sehingga nantinya mereka dapat memberikan penjelasan dan alasan-alasan yang kuat agar pelanggannya mau menggunakan kondom. Green menyatakan penyebab perilaku seseorang adalah karena adanya alasan pemikiran dan perasaan dalam bentuk pengetahuan. Pengetahuan dapat membentuk keyakinan tertentu sehingga seseorang berperilaku sesuai dengan keyakinan tersebut. Sumber pengetahuan dapat diperoleh dari bermacam-macam sumber misalnya media 
cetak, media elektronik, buku petunjuk, petugas kesehatan, media poster, brosur, teman, dan sebagainya. Upaya-upaya untuk meningkatkan pengetahuan PSK tersebut dapat dilakukan dengan cara penyuluhan secara rutin dengan melibatkan berbagai komponen, baik pemerintah, swasta, LSM maupun masyarakat lingkungan lokalisasi. Penyuluhan atau penyampaian informasi untuk meningkatkan pengetahuan PSK tentang kondom ini, dapat dilakukan secara langsung, yaitu dengan cara mendatangi lokalisasi tempat beroperasinya PSK tersebut, atau seperti yang dinyatakan oleh WHO yaitu dengan cara memanfaatkan media massa berupa buku, majalah, koran, brosur, leaflet atau media massa lainnya. (Kenderweis, 2010:25)

\section{b. Faktor Sikap}

Berdasarkan hasil penelitian ini variabel sikap berpengaruh terhadap kemampuan tawarpenggunaan kondom oleh PSK kepada pelanggannya. Hal ini mengandung arti jika PSK mempunyai sikap positif, diproyeksikan akan menawarkan kondom kepada pelanggannya. Sikap mau menawarkan kondom akan terbentuk apabila PSK mempunyai pengetahuan yang positif tentang manfaat kondom bagi dirinya atau pelanggannya. Oleh karena itu, agar dalam diri PSK terbentuk sikap positif terhadap penggunaan kondom, harus dilakukan upaya-upaya peningkatan pengetahuan PSK tentang penggunaan kondom dan manfaat-manfaatnya, baik bagi dirinya sendiri maupun bagi pelanggannya. Hal ini dapat dilakukan dengan penyuluhan secara terusmenerus dan konsisten. Upaya perbaikan sikap ini sangat diperlukan, karena berdasarkan hasil penelitian, sikap PSK di Kabupaten Langkat terhadap penggunaan kondom masih belum baik; hanya 27,9\% PSK yang mempunyai sikap baik. Kegiatan untuk perbaikan sikap ini juga dapat dilakukan dengan cara seperti yang diungkapkan oleh Pakpahan pada lokalisasi yang disebut "warung bebek" di Kabupaten Serdang Bedagai, yaitu dengan cara melakukan pendidikan sebaya, di mana PSK yang dididik kemudian berfungsi sebagai pendamping lapangan bagi PSK yang lainnya. Dengan demikian PSK tersebut dapat dengan mudah memberikan transfer ilmu tentang kondom dan pencegahan HIV/AIDS kepada kawan- kawannya. (Kenderweis, 2010:26).

\subsection{Penelitian yang dilakukan oleh Andi Fadhali dkk mengenai Faktor yang Berhubungan dengan Pencegahan HIV dan AIDS di Kalangan Pramusaji Kafe di Tanjung Bira Kabupaten Bulukumba.}

Hasil penelitian Hubungan Pengetahuan dengan praktek pencegahan HIV dan AIDS di Kalangan Pramusaji

Hasil uji analisis bivariat uji chi-square (nilai $p=0,002<0,05$ ) ada hubungan yang bermakna antara pengetahuan dengan praktek pencegahan. Secara proporsi menunjukkan bahwa pramusaji melakukan praktek pencegahan secara baik lebih besar pada pramusaji yang memiliki pengetahuan tinggi dibandingkan dengan pramusaji yang memiliki pengetahuan rendah. Artinya semakin tinggi pengetahuan pramusaji maka semakin baik pula dalam mencegah penularan HIV dan AIDS, seperti tidak melakukan hubungan seks bebas kepelanggan atau konsisten menggunakan kondom. Semakin rendahnya pengetahuan pramusaji maka semakin rendah pula dalam melakukan pencegahan. Hal ini terjadi karena berdasarkan hasil penelitian menunjukkan rata-rata pramusaji mampu menjawab benar pertanyaan tentang HIV dan AIDS. Pengertian HIV dan AIDS 48,7 \%, yang diserang HIV dan AIDS 47,4 \%, pengertian HIV 71,1\%, media penularan HIV 59,2\%, orang yang bisa terinfeksi HIV 60,5 \% dan penggunaan jarum suntik 67,\%. (Fadhali, 2012). 


\subsection{Penelitian yang dilakukan oleh Juliastika dkk mengenai Hubungan Pengetahuan tentang HIV/AIDS dengan Sikap dan Tindakan Penggunaan Kondom Pria pada Wanita Pekerja Seks di Kota Manado.}

Populasi penelitian adalah seluruh wanita pekerja seks yang ada di Manado pada tahun 2011 dengan jumlah sebanyak 250 orang. Jumlah sampel yang diambil sebanyak 71 responden. Hasil uji statistik Chi Square dengan batas kemaknaan 0,05 $(\mathrm{p}=0,05)$ diperoleh nilai $\mathrm{p}=0,022$ yang menunjukkan bahwa adanya hubungan bermakna antara pengetahuan responden tentang HIV/AIDS dengan tindakan penggunaan kondom pria pada wanita pekerja seks. Hasil tersebut sejalan dengan hasil penelitian di Soelistijani (2003) di Bali bahwa hubungan antara pengetahuan tentang HIV/AIDS dengan tindakan penggunaan kondom menunjukkan hubungan yang bermakna ( $\mathrm{p}=0,008)$. Demikian pula hasil penelitian oleh Supardi (2010) di Kabupaten Merauke menunjukkan adanya hubungan yang bermakna antara kedua variabel tersebut. Hasil penelitian ini sesuai dengan teori Green dalam Notoatmodjo (2010) bahwa perilaku seseorang tentang kesehatan dalam hal ini tindakan terhadap penggunaan kondom pria salah satunya dipengaruhi oleh pengetahuan (faktor predisposisi) ( Juliastika, 2011).

\section{Tujuan Penelitian}

- Tujuan umum :

Untuk mengetahui hubungan pengetahuan tentang HIV/AIDS dengan sikap dan tindakan penggunaan kondom pada wanita pekerja seks di wilayah lokalisasi km 12 Palangka Raya.

- Tujuan khusus :

- Mengetahui persentase pengetahuan wanita pekerja seks di wilayah lokalisasi km 12 Palangka Raya tentang HIV/AIDS.

- Mengetahui persentase sikap wanita pekerja seks di wilayah lokalisasi km 12 Palangka Raya dalam menggunakan kondom.

- Mengetahui persentase tindakan wanita pekerja seks di wilayah lokalisasi km 12 Palangka Raya dalam menggunakan kondom.

- Menganalisis hubungan pengetahuan tentang HIV/AIDS dengan sikap penggunaan kondom pada wanita pekerja seks di wilayah lokalisasi km 12 Palangka Raya.

- Menganalisis hubungan pengetahuan tentang HIV/AIDS dengan tindakan penggunaan kondom pada wanita pekerja seks di wilayah lokalisasi km 12 Palangka Raya.

\section{Metode}

\section{A. Tahapan-tahapan Penelitian}

Penelitian ini terdiri dari beberapa tahapan antara lain :

\section{Tahap Persiapan}

Tahap persiapan ini meliputi :

a. Persiapan proposal penelitian melalui studi pustaka.

b. Sosialisasi dengan pihak pengelola lokalisasi km 12 Palangka Raya.

c. Penentuan WPS yang akan menjadi responden melalui survey data identitas yang kemudian akan ditentukan jumlah responden.

\section{Tahap Pelaksanaan}

a. Tim Peneliti datang ke lokasi penelitian untuk memberikan pengarahan dan informasi kepada Wanita Pekerja Seks sebagai responden mengenai penelitian yang akan dilakukan.

b. Pembagian kuesioner kepada responden tentang pengetahuan pencegahan HIV/AIDS, sikap dalam penggunaan kondom dan tindakan/praktik penggunaan kondom. 
c. Pengisian kuesioner yang dilakukan oleh responden tentang pengetahuan pencegahan HIV/AIDS, sikap dalam penggunaan kondom dan tindakan/praktik penggunaan kondom.

d. Wawancara/interview mendalam mengenai HIV/AIDS dan praktik penggunaan kondom.

\section{Tahap Pengolahan data dan Pelaporan}

a. Kuesioner yang telah lengkap diisi oleh responden diolah datanya sesuai definisi operasional yang telah ditetapkan.

b. Dilakukan analisa data dengan uji Chi-square dengan tingkat kemaknaan 95\% (p < 0,05) menggunakan program SPSS 11.5 for windows.

c. Interpretasi data, pembahasan hasil penelitian dan penarikan kesimpulan penelitian sesuai tujuan penelitian.

d. Pembuatan laporan hasil penelitian dan publikasi melalui jurnal lokal yang mempunyai ISSN.

B. Lokasi Penelitian

Lokalisasi km 12 Palangka Raya.

C. Kerangka Konsep

\section{Variabel Bebas}

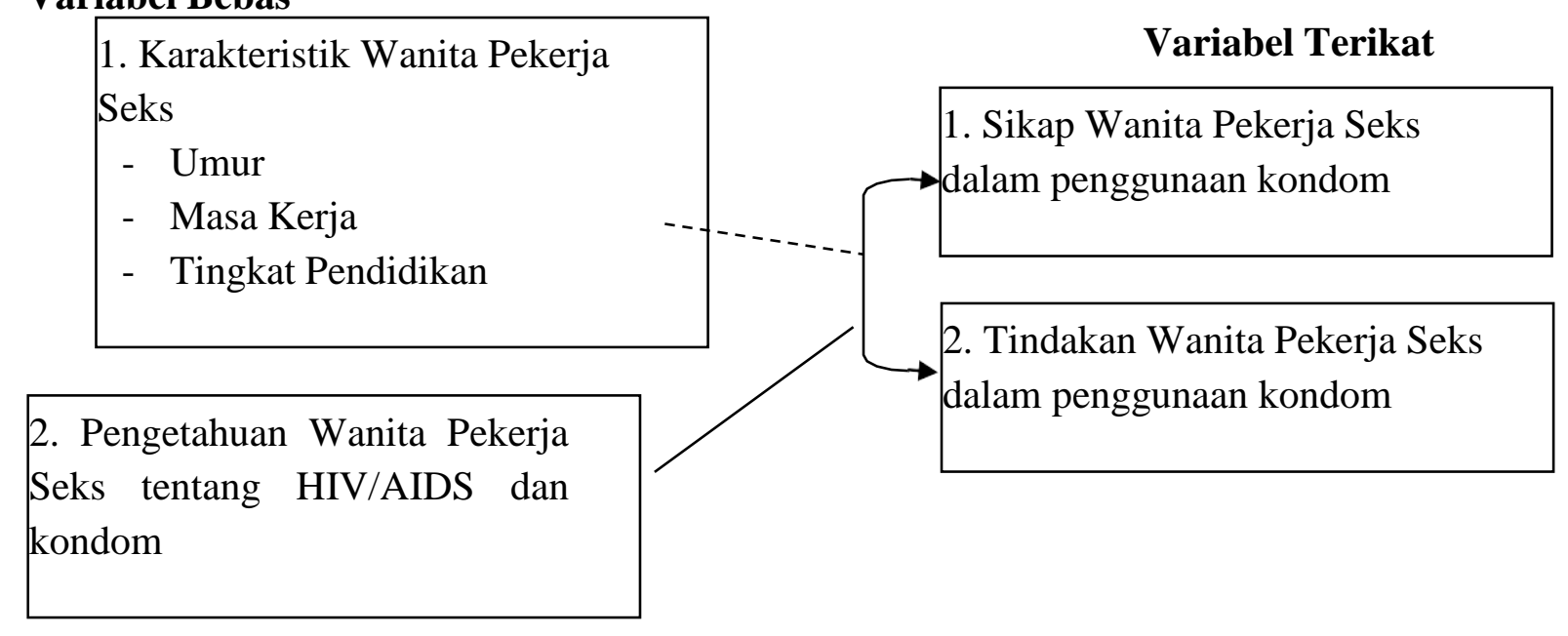

Variabel bebas pada kerangka konsep penelitian ini yang akan diteliti adalah pengetahuan responden yang meliputi tentang HIV/AIDS dan kondom.

\section{Hipotesis Penelitian}

- Terima Ho : tidak terdapat perbedaan persentase yang bermakna antara WPS berpengetahuan baik tentang HIV/AIDS dengan WPS berpengetahuan buruk dengan sikap dan tindakan penggunaan kondom.

- Terima H1 : terdapat perbedaan persentase yang bermakna antara WPS berpengetahuan baik tentang HIV/AIDS dengan WPS berpengetahuan buruk dengan sikap dan tindakan penggunaan kondom.

\section{E. Definisi Operasional}

1. Umur : penggolongan usia WPS dalam tahun, dihitung mulai dari tanggal lahir sampai dengan pada saat wawancara. 
Kategori

: Muda, usia 15-25 tahun

Dewasa, usia 26-34 tahun Tua, usia $\geq 35$ tahun

2. Masa kerja WPS adalah jumlah tahun WPS yang bekerja di lokalisasi km 12 Palangka Raya.

Skala

: Ordinal

Kategori

: Baru, $<1$ tahun

Sedang, 1-5 tahun Lama, $>5$ tahun

3. Tingkat pendidikan adalah tingkat sekolah formal yang pernah diikuti WPS berdasarkan ijazah terakhir yang dimiliki.

Skala

: Ordinal

Kategori

: Tidak sekolah, SD, SLTP, SLTA, Sarjana

4. Pengetahuan WPS tentang HIV/AIDS dan kondom adalah kemampuan responden dalam menjawab pertanyaan yang meliputi pengertian, tanda dan gejala, cara mencegah HIV/AIDS, cara menggunakan kondom serta manfaat dan dampak jika tidak menggunakan kondom. Cara pemberian skor, bila jawaban benar skor 1 dan bila jawaban salah skor 0 . Jumlah pernyataan pengetahuan sebanyak 16 pernyataan dengan skala ordinal dan tingkat pengetahuan dibagi dalam tiga tingkatan yaitu baik, sedang dan buruk.

Kategori : Baik, bila $\ddot{x}+1 / 2$ SD

Sedang, bila $\ddot{x} \pm 1 / 2$ SD Buruk, bila $\ddot{x}-1 / 2$ SD

5. Sikap WPS terhadap cara mencegah HIV/AIDS dengan menggunakan kondom adalah tanggapan atau responden dalam menjawab pernyataan yang meliputi pengertian, tanda dan gejala, cara mencegah HIV/AIDS, cara menggunakan kondom serta manfaat dan dampak jika tidak menggunakan kondom. Cara pemberian skor untuk pernyataan positif sangat setuju skor 2, setuju skor 1 , tidak

setuju skor 0 . Pernyataan negatif sangat ${ }^{\text {setuju }}$ skor 0 , setuju skor 1 , tidak setuju skor

2. Jumlah pernyataan sikap sebanyak 10 pernyataan dengan skala ordinal dan tingkat sikap

WPS dibagi dalam tiga tingkatan yaitu baik, sedang, buruk.

Kategori : Baik, bila $\ddot{x}+1 / 2$ SD

Sedang, bila $\ddot{x} \pm 1 / 2$ SD Buruk, bila $\ddot{x}-1 / 2$ SD

6. Tindakan atau praktik WPS dalam penggunaan kondom adalah aksi atau kegiatan WPS yang meliputi pengenalan kondom pada pelanggan dengan cara memberikan penjelasan tentang manfaat kondom dan informasi tentang HIV/AIDS, menawarkan kondom pada pelanggan dengan cara mengajak pelanggan menggunakan kondom saat melakukan hubungan seksual. Cara pemberian skor, bila jawaban selalu skor 2, bila jawaban kadang-kadang skor 1, bila jawaban tidak pernah skor 0. Jumlah pernyataan tindakan WPS dalam penggunaan kondom sebanyak 6 pernyataan dengan skala ordinal dan tingkat tindakan WPS dibagi dalam dua tingkatan baik dan buruk.

Kategori $\quad$ : Baik, bila $\geq$ median

Buruk, bila $<$ median

\section{F. Jenis Penelitian}

Penelitian ini merupakan Explanatory Research yang menjelaskan hubungan antara variabel bebas dengan variabel terikat melalui pengujian hipotesa yang telah dirumuskan. 


\section{G. Metode Penelitian}

Metode penelitian yang digunakan adalah metode survey sampel yaitu penelitian yang mengambil sampel dari suatu populasi dengan menggunakan kuesioner sebagai alat pengumpul data yang pokok.

\section{H. Populasi, sampel dan besar sampel}

1. Populasi

Populasi penelitian adalah para WPS yang bekerja di lokalisasi km 12 Palangka Raya.

2. Sampel

Sampel yang diambil dalam penelitian ini adalah WPS yang ada dilokalisasi km 12 Palangka Raya dengan kriteria inklusi yaitu WPS yang telah mempunyai masa kerja minimal 1 bulan.

3. Besar Sampel

Jumlah responden yang digunakan penentuannya dilakukan dengan teknik sampling menggunakan rumus slovin $\mathrm{N}$

Dimana :

$$
\mathrm{N}=
$$

$$
\begin{array}{ll}
\mathrm{n} & =\text { Ukuran Sampel } \\
\mathrm{N} & =\text { Ukuran Populasi }
\end{array}
$$

d \& e = Tingkat kesalahan pengambilan sampel yang dapat ditolerir (presisi), dengan presisi $10 \%$

Jumlah WPS dilokalisasi km 12 Palangka Raya adalah 140 orang ( KPA, 2013) dengan teknik sampling menjadi 59 orang, ditambah toleransi $10 \%$ untuk mengantisipasi responden yang drop out sehingga jumlah responden menjadi 65 orang.

\section{Teknik Pengambilan Sampel}

Teknik pengambilan sampel dilakukan secara acak sederhana (Simple Random Sampling) yaitu semua WPS yang ada dilokalisasi km 12 Palangka Raya sebanyak 140 orang didaftar dan dibuat nomor urutnya. Berdasarkan daftar tersebut dipilih secara random sehingga mendapatkan jumlah 65 orang. Caranya dimulai dengan memilih sampel yang pertama kali kemudian pengambilan sampel berikutnya dilakukan dengan cara membagi jumlah populasi dengan jumlah sampel ( $140: 65= \pm 2$ ). Dengan cara mengurutkan setiap 2 orang responden akan diperoleh satu sampel. Kegiatan ini dilakukan terus secara berurutan sampai memperoleh sampel sejumlah 65 orang.

\section{J. Sumber Data Penelitian/Teknik Pengumpulan Data}

Data yang digunakan dalam analisis dan untuk menarik kesimpulan dalam penelitian ini adalah data primer. Data primer yaitu data yang diperoleh langsung dari sumbernya, diamati dan dicatat untuk pertama kalinya. Data primer ini dikumpulkan melalui wawancara dengan menggunakan kuesioner yang telah disiapkan sesuai tujuan penelitian.

\section{K. Pengolahan data}

Pengolahan data dilakukan dengan menggunakan SPSS 11.5. Adapun langkah- langkah pengolahan data sebagai berikut :

1. Editing yaitu langkah yang dilakukan untuk memeriksa kelengkapan, konsistensi maupun kesalahan jawaban pada kuesioner. 
2. Koding dilakukan untuk memudahkan dalam proses pengolahan data.

3. Tabulasi merupakan lanjutan langkah koding untuk mengelompokkan data kedalam suatu data tertentu menurut sifat yang dimiliki sesuai dengan tujuan penelitian.

4. Penyajian data dilakukan dengan menggunakan tabel, grafik dan narasi.

\section{Analisis Data}

Data diolah dan dianalisis dengan bantuan SPSS 11.5 berupa tabulasi data dan untuk mengetahui hubungan variabel bebas dengan variabel terikat dalam pernyataan hipotesis. Analisis yang digunakan adalah analisis univariat dan analisis bivariat.

1. Analisis univariat

Dilakukan untuk memberikan gambaran secara umum terhadap variabel karakteristik responden berupa umur, masa kerja dan tingkat pendidikan. Analisis data responden menggunakan persentase sehingga penyajiannya dalam bentuk tabel dan distribusi frekuensi.

2. Analisis bivariat

a. Tabulasi silang

Dilakukan untuk menyajikan data dalam bentuk tabel yang meliputi baris dan kolom. Analisis ini untuk melihat pola atau kecenderungan hubungan dua variabel yang diteliti dan dibuat dalam bentuk tabel distribusi dari variabel penelitian yang dikelompokkan sesuai dengan pengelompokkan skor.

b. Uji Hipotesis

Analisis bivariat ini dilakukan dengan analisis statistik chi square $(\mathrm{p}<0.05)$. Tujuan analisis ini adalah untuk mengetahui ada hubungan yang signifikan antara masing-masing variabel bebas dengan variabel terikat. Dasar pengambilan keputusan (berdasarkan tingkat kemaknaan) :

- Jika tingkat kemaknaan (p) >0.05 atau chi-square hitung < chi-square tabel maka Ho diterima.

- Jika tingkat kemaknaan (p) $<0.05$ atau chi-square hitung $>$ chi-square tabel maka Ho ditolak.

\section{Uji Validitas dan Reliabilitas Kuesioner}

Uji validitas dan reliabilitas dilakukan untuk melihat sejauh mana alat ukur dapat dipercaya dan dapat diandalkan untuk digunakan sebagai alat pengumpul data.

1. Uji Validitas

Uji validitas dilakukan untuk mengetahui sejauh mana ketepatan dan kecermatan suatu alat dalam melakukan fungsi ukurnya. Uji validitas kuesioner dilakukan terhadap 30 responden yang dilakukan diluar daerah penelitian yang mempunyai spesifitas yang hampir sama. Dalam uji validitas, setiap item pertanyaan dilakukan uji validitas terhadap total skor seluruh pertanyaan tersebut dengan menggunakan uju Person Product Moment. Apabila hasil uji tersebut untuk setiap item pertanyaan ternyata signifikan ( $\mathrm{p}$ value $<5 \%$ ) maka item pertanyaan tersebut sudah valid dan bisa digunakan. Apabila tidak signifikan ( $\mathrm{p}$ value $>5 \%$ ) maka item pertanyaan tersebut tidak valid dan harus didrop dari kuesioner (Arikunto, 2006). Kuesioner yang digunakan dalam penelitian ini mengadopsi kuesioner Tri Susilo Hadi dalam tesisnya yang berjudul “ Faktorfaktor yang mempengaruhi praktik Negosiasi Penggunaan Kondom Untuk Mencegah IMS dan HIV/AIDS pada WPS di Resosialisasi Argorejo Kelurahan Kalibanteng Kulon Kecamatan Semarang Barat Kota Semarang”. Hasil uji validitas item pertanyaan kuesioner pengetahuan pencegahan HIV dan AIDS dari 98 pernyataan yang diuji dengan korelasi product moment menunjukkan 16 pernyataan pengetahuan pencegahan HIV/AIDS yang valid. Hasil uji validitas sikap WPS tentang 
penggunaan kondom dari 14 item pernyataan sikap yang diuji dengan korelasi product moment menunjukkan 10 pernyataan yang valid ( Hadi, 2004).

\section{Uji Reliabilitas}

Pengukuran reliabilitas berarti mengukur sejauh mana hasil suatu pengukuran dapat dipercaya. Hasil pengukuran dapat dipercaya apabila dalam beberapa kali pelaksanaan pengukuran terhadap kelompok subyek yang sama diperoleh hasil yang relative sama selama aspek yang diukur dalam arti subyek belum berubah. Dalam uji reliabilitas, item-item pertanyaan yang sudah valid diuji reliabilitasnya dengan menggunakan koefisien alpha. Apabila alpha yang diperoleh dari uji reliabilitas ini lebih besar dari 0,75 maka instrumen penelitian tersebut telah reliable atau termasuk kriteria kesepakatan sangat baik. Apabila alpha lebih besar dari 0,4 dan kurang dari 0,75 termasuk kriteria kesepakatan cukup baik (Arikunto, 2006). Hasil uji reliabilitas yang dilakukan Tri Susilo dalam penelitian tesisnya diperoleh angka untuk variabel pengetahuan pencegahan HIV/AIDS sebesar 0,9173 (kesepakatan sangat baik), variabel sikap WPS dalam penggunaan kondom 0,6113 (kesepakatan cukup baik) dan variabel praktik/tindakan penggunaan kondom sebesar 0,6106 (kesepakatan cukup baik) (Hadi, 2004).

\section{E. Hasil dan Pembahasan}

A. Hasil Penelitian

Penelitian dilakukan dengan metode survey sampel pada wanita pekerja seks di lokalisasi km 12 Palangka Raya. Data dikumpulkan melalui proses wawancara menggunakan kuesioner yang diberikan kepada 60 responden. Berdasarkan hal tersebut didapatkan data berupa data umum dan data khusus. Data umum yang diperoleh berupa umur responden, masa kerja dan tingkat pendidikan. Data khusus yang diperoleh antara lain identifikasi pengetahuan responden mengenai HIV/AIDS dan kondom, identifikasi sikap responden dalam mencegah HIV/AIDS menggunakan kondom, identifikasi tindakan responden dalam menggunakan kondom, analisis hubungan antara pengetahuan responden mengenai HIV/AIDS dan kondom dengan sikap responden dalam mencegah HIV/AIDS menggunakan kondom serta analisis hubungan antara pengetahuan responden mengenai HIV/AIDS dan kondom dengan tindakan responden dalam menggunakan kondom.

\subsection{Data Umum/Karakteristik Responden}

\subsubsection{Umur Responden}

Umur wanita pekerja seks yang menjadi responden terbanyak pada umur 26-34 tahun yaitu 31 orang (51,7\%), umur 15-25 tahun sebanyak 20 orang (33,3\%) dan terkecil usia $\geq 35$ tahun sebanyak 9 orang (15\%). Hal ini menunjukkan umur responden yang semakin dewasa akan membuat individu yang bersangkutan melakukan adaptasi perilaku terhadap lingkungan. Penyebab yang sering dikemukakan seseorang memilih menjadi wanita pekerja seks karena lingkungan atau sekitarnya yang mempengaruhi untuk memilih profesi tersebut yaitu pengaruh oleh teman atau tetangganya yang lebih dahulu sudah menjadi wanita pekerja seks.

\begin{tabular}{|c|l|c|c|}
\hline No & Kelompok Umur & Jumlah & Prosentase \\
\hline 1 & $15-25$ tahun & 20 & $33,3 \%$ \\
\hline 2 & $26-34$ tahun & 31 & $51,7 \%$ \\
\hline 3 & $\geq 35$ tahun & 9 & $15 \%$ \\
\hline \multicolumn{2}{|c|}{ Total } & $\mathbf{6 0}$ & $\mathbf{1 0 0 \%}$ \\
\hline
\end{tabular}

Tabel 5.1 Distribusi frekuensi responden berdasarkan umur wanita pekerja seks di lokalisasi km 12 Palangka Raya 


\subsubsection{Masa Kerja Responden}

Masa kerja wanita pekerja seks yang menjadi responden terbanyak dengan masa kerja $<1$ tahun yaitu 32 orang (53,3\%), masa kerja 1-5 tahun sebanyak 28 orang (46,7\%) dan tidak ada (0\%) yang memiliki masa kerja $>5$ tahun. Hal ini menunjukkan proses rotasi wanita pekerja seks dari satu tempat ke tempat lain sangat tinggi. Rotasi ini biasanya dipengaruhi oleh banyak sedikitnya pelanggan yang dilayani selama wanita pekerja seks berada dilokalisasi.

\begin{tabular}{|c|l|c|c|}
\hline No & \multicolumn{1}{|c|}{ Masa Kerja } & Jumlah & Prosentase \\
\hline 1 & $<1$ tahun & 32 & $53,3 \%$ \\
\hline 2 & $1-5$ tahun & 28 & $46,7 \%$ \\
\hline 3 & $>5$ tahun & 0 & $0 \%$ \\
\hline & Total & $\mathbf{6 0}$ & $\mathbf{1 0 0} \%$ \\
\hline
\end{tabular}

Tabel 5.2 Distribusi frekuensi responden berdasarkan masa kerja wanita pekerja seks di lokalisasi km 12 Palangka Raya

\subsubsection{Tingkat Pendidikan Responden}

Tingkat pendidikan yang pernah ditempuh wanita pekerja seks yang menjadi responden terbanyak adalah SLTP yaitu 32 orang (53,3\%), SD sebanyak 16 orang (26,7\%), SLTA sebanyak 12 orang (20\%) dan sisanya tidak sekolah dan sarjana sebanyak 0 orang (0\%). Rendahnya tingkat pendidikan yang pernah ditempuh menimbulkan kurangnya pengertian dan keterampilan sehingga membuat individu menghindar dari kesulitan hidup dan mencari kesenangan melalui jalan pendek salah satunya dengan menjadi wanita pekerja seks.

\begin{tabular}{|c|c|c|c|}
\hline No Kelompok Umur & Jumlah & Prosentase \\
\hline 1 & Tidak Sekolah & 0 & $0 \%$ \\
\hline 2 & SD & 16 & $26,7 \%$ \\
\hline 3 & SLTP & 32 & $53,3 \%$ \\
\hline 4 & SLTA & 12 & $20 \%$ \\
\hline 5 & Sarjana & 0 & $0 \%$ \\
\hline & Total & $\mathbf{6 0}$ & $\mathbf{1 0 0 \%}$ \\
\hline
\end{tabular}

Tabel 5.3 Distribusi frekuensi responden berdasarkan tingkat pendidikan wanita pekerja seks di lokalisasi km 12 Palangka Raya

\subsection{Data Khusus}

\subsubsection{Pengetahuan Responden mengenai HIV/AIDS dan kondom}

Kuesioner yang berisi pernyataan mengenai pengetahuan responden terkait HIV/AIDS dan kondom dilakukan penilaian dan didapatkan $\ddot{\mathrm{x}}=13$ dan $\mathrm{SD}=2,255$. Dari nilai tersebut dapat ditentukan kategori pengetahuan sebagai berikut :

- Baik jika nilai responden $>15,255$

- $\quad$ Sedang jika nilai responden $=11,255-15,255$

- Buruk jika nilai responden $<11,255$

\begin{tabular}{|c|c|c|c|c|c|}
\hline Responden & Skor & Responden & Skor & Responden & Skor \\
\hline $\mathbf{1}$ & 13 & $\mathbf{2 3}$ & 9 & $\mathbf{4 5}$ & 10 \\
\hline $\mathbf{2}$ & 13 & $\mathbf{2 4}$ & 16 & $\mathbf{4 6}$ & 14 \\
\hline $\mathbf{3}$ & 12 & $\mathbf{2 5}$ & 15 & $\mathbf{4 7}$ & 13 \\
\hline $\mathbf{4}$ & 10 & $\mathbf{2 6}$ & 15 & $\mathbf{4 8}$ & 14 \\
\hline $\mathbf{5}$ & 12 & $\mathbf{2 7}$ & 15 & $\mathbf{4 9}$ & 13 \\
\hline
\end{tabular}




\begin{tabular}{|c|c|c|c|c|c|}
\hline 6 & 15 & 28 & 15 & 50 & 10 \\
\hline 7 & 14 & 29 & 15 & 51 & 5 \\
\hline 8 & 11 & 30 & 15 & 52 & 15 \\
\hline 9 & 16 & 31 & 14 & 53 & 7 \\
\hline 10 & 13 & 32 & 13 & 54 & 10 \\
\hline 11 & 14 & 33 & 13 & 55 & 11 \\
\hline 12 & 14 & 34 & 14 & 56 & 14 \\
\hline 13 & 16 & 35 & 14 & 57 & 16 \\
\hline 14 & 15 & 36 & 14 & 58 & 13 \\
\hline 15 & 15 & 37 & 16 & 59 & 13 \\
\hline 16 & 12 & 38 & 13 & 60 & 10 \\
\hline 17 & 14 & 39 & 13 & & \\
\hline 18 & 13 & 40 & 13 & & \\
\hline 19 & 13 & 41 & 14 & & \\
\hline 20 & 14 & 42 & 11 & & \\
\hline 21 & 14 & 43 & 10 & & \\
\hline 22 & 9 & 44 & 13 & & \\
\hline
\end{tabular}

Tabel 5.4 Rekapan Penilaian Pengetahuan Responden mengenai HIV/AIDS dan kondom

Pengetahuan wanita pekerja seks yang menjadi responden mengenai HIV/AIDS dan kondom sebanyak 43 orang $(71,7 \%)$ memiliki pengetahuan sedang, 12 orang (20\%) memiliki pengetahuan buruk dan sisanya 5 orang $(8,3 \%)$ memiliki pengetahuan baik.

\begin{tabular}{|c|l|c|c|}
\hline No & \multicolumn{1}{|c|}{ Pengetahuan } & Jumlah & Prosentase \\
\hline 1 & Baik & 5 & $8,3 \%$ \\
\hline 2 & Sedang & 43 & $71,7 \%$ \\
\hline 3 & Buruk & 12 & $20 \%$ \\
\hline & Total & $\mathbf{6 0}$ & $\mathbf{1 0 0 \%}$ \\
\hline
\end{tabular}

Tabel 5.5 Distribusi frekuensi kategori pengetahuan wanita pekerja seks di lokalisasi km 12 Palangka Raya mengenai HIV/AIDS dan kondom

\subsubsection{Sikap Responden dalam mencegah HIV/AIDS dengan penggunaan kondom}

Kuesioner yang berisi pernyataan mengenai sikap responden dalam mencegah HIV/AIDS dengan penggunaan kondom dilakukan penilaian dan didapatkan $\ddot{\mathrm{x}}=15,18$ dan SD = 5,074. Dari nilai tersebut dapat ditentukan kategori sikap responden sebagai berikut :

- Baik jika nilai responden $>20,3$

- $\quad$ Sedang jika nilai responden $=10,1-20,3$

- $\quad$ Buruk jika nilai responden $<10,1$

\begin{tabular}{|c|c|c|c|c|c|}
\hline Responden & Skor & Responden & Skor & Responden & Skor \\
\hline $\mathbf{1}$ & 10 & $\mathbf{2 3}$ & 2 & $\mathbf{4 5}$ & 12 \\
\hline $\mathbf{2}$ & 20 & $\mathbf{2 4}$ & 20 & $\mathbf{4 6}$ & 17 \\
\hline $\mathbf{3}$ & 18 & $\mathbf{2 5}$ & 18 & $\mathbf{4 7}$ & 17 \\
\hline $\mathbf{4}$ & 0 & $\mathbf{2 6}$ & 18 & $\mathbf{4 8}$ & 17 \\
\hline $\mathbf{5}$ & 18 & $\mathbf{2 7}$ & 20 & $\mathbf{4 9}$ & 12 \\
\hline $\mathbf{6}$ & 18 & $\mathbf{2 8}$ & 18 & $\mathbf{5 0}$ & 16 \\
\hline $\mathbf{7}$ & 16 & $\mathbf{2 9}$ & 18 & $\mathbf{5 1}$ & 2 \\
\hline $\mathbf{8}$ & 11 & $\mathbf{3 0}$ & 18 & $\mathbf{5 2}$ & 12 \\
\hline
\end{tabular}




\begin{tabular}{|c|c|c|c|c|c|}
\hline $\mathbf{9}$ & 17 & $\mathbf{3 1}$ & 14 & $\mathbf{5 3}$ & 0 \\
\hline $\mathbf{1 0}$ & 20 & $\mathbf{3 2}$ & 15 & $\mathbf{5 4}$ & 20 \\
\hline $\mathbf{1 1}$ & 20 & $\mathbf{3 3}$ & 15 & $\mathbf{5 5}$ & 12 \\
\hline $\mathbf{1 2}$ & 16 & $\mathbf{3 4}$ & 15 & $\mathbf{5 6}$ & 14 \\
\hline $\mathbf{1 3}$ & 20 & $\mathbf{3 5}$ & 14 & $\mathbf{5 7}$ & 20 \\
\hline $\mathbf{1 4}$ & 17 & $\mathbf{3 6}$ & 14 & $\mathbf{5 8}$ & 14 \\
\hline $\mathbf{1 6}$ & 18 & $\mathbf{3 7}$ & 20 & $\mathbf{5 9}$ & 18 \\
\hline $\mathbf{1 7}$ & 20 & $\mathbf{3 8}$ & 15 & $\mathbf{6 0}$ & \multirow{2}{*}{1} \\
\hline $\mathbf{1 8}$ & 17 & $\mathbf{3 9}$ & 15 & & \\
\cline { 1 - 3 } $\mathbf{1 9}$ & 20 & $\mathbf{4 0}$ & 13 & & \\
\cline { 1 - 3 } $\mathbf{2 1}$ & 16 & $\mathbf{4 1}$ & 18 & & \\
\cline { 1 - 3 } $\mathbf{2 2}$ & 0 & $\mathbf{4 2}$ & 16 & & \\
\end{tabular}

Tabel 5.6 Rekapan Penilaian Sikap Responden dalam mencegah HIV/AIDS dengan penggunaan kondom

Sikap wanita pekerja seks yang menjadi responden dalam menggunakan kondom untuk mencegah HIV/AIDS terbanyak memiliki sikap sedang yaitu 54 orang (90\%), sikap buruk sebanyak 6 orang (10\%) dan tidak ada (0\%) wanita pekerja seks yang memiliki sikap baik dalam menggunakan kondom.

\begin{tabular}{|c|l|c|c|}
\hline No & \multicolumn{1}{|c|}{ Sikap } & Jumlah & Prosentase \\
\hline 1 & Baik & 0 & $0 \%$ \\
\hline 2 & Sedang & 54 & $90 \%$ \\
\hline 3 & Buruk & 6 & $10 \%$ \\
\hline & Total & $\mathbf{6 0}$ & $\mathbf{1 0 0 \%}$ \\
\hline
\end{tabular}

Tabel 5.7 Distribusi frekuensi kategori sikap wanita pekerja seks di lokalisasi km 12

Palangka Raya dalam mencegah HIV/AIDS menggunakan kondom

\subsubsection{Tindakan Responden dalam penggunaan kondom}

Kuesioner yang berisi pernyataan mengenai tindakan responden dalam penggunaan kondom dilakukan penilaian dan didapatkan nilai median $=11$. Dari nilai tersebut dapat ditentukan kategori tindakan responden sebagai berikut :

- $\quad$ Baik jika nilai responden $\geq 11$

- Buruk jika nilai responden $<11$

\begin{tabular}{|c|c|c|c|c|c|}
\hline Responden & Skor & Responden & Skor & Responden & Skor \\
\hline $\mathbf{1}$ & 6 & $\mathbf{2 3}$ & 12 & $\mathbf{4 5}$ & 7 \\
\hline $\mathbf{2}$ & 7 & $\mathbf{2 4}$ & 12 & $\mathbf{4 6}$ & 10 \\
\hline $\mathbf{3}$ & 8 & $\mathbf{2 5}$ & 11 & $\mathbf{4 7}$ & 12 \\
\hline $\mathbf{4}$ & 10 & $\mathbf{2 6}$ & 11 & $\mathbf{4 8}$ & 12 \\
\hline $\mathbf{5}$ & 10 & $\mathbf{2 7}$ & 12 & $\mathbf{4 9}$ & 11 \\
\hline $\mathbf{6}$ & 11 & $\mathbf{2 8}$ & 11 & $\mathbf{5 0}$ & 3 \\
\hline $\mathbf{7}$ & 12 & $\mathbf{2 9}$ & 11 & $\mathbf{5 1}$ & 12 \\
\hline $\mathbf{8}$ & 11 & $\mathbf{3 0}$ & 11 & $\mathbf{5 2}$ & 9 \\
\hline $\mathbf{9}$ & 8 & $\mathbf{3 1}$ & 11 & $\mathbf{5 3}$ & 6 \\
\hline $\mathbf{1 0}$ & 12 & $\mathbf{3 2}$ & 11 & $\mathbf{5 4}$ & 10 \\
\hline
\end{tabular}




\begin{tabular}{|l|c|c|c|c|c|}
\hline $\mathbf{1 1}$ & 12 & $\mathbf{3 3}$ & 11 & $\mathbf{5 5}$ & 5 \\
\hline $\mathbf{1 2}$ & 12 & $\mathbf{3 4}$ & 11 & $\mathbf{5 6}$ & 11 \\
\hline $\mathbf{1 3}$ & 12 & $\mathbf{3 5}$ & 11 & $\mathbf{5 7}$ & 12 \\
\hline $\mathbf{1 4}$ & 10 & $\mathbf{3 6}$ & 11 & $\mathbf{5 8}$ & 11 \\
\hline $\mathbf{1 6}$ & 10 & $\mathbf{3 7}$ & 12 & $\mathbf{5 9}$ & 11 \\
\hline $\mathbf{1 7}$ & 12 & $\mathbf{3 8}$ & 11 & $\mathbf{6 0}$ & 9 \\
\hline $\mathbf{1 8}$ & 10 & $\mathbf{3 9}$ & 11 & & \\
\cline { 1 - 3 } $\mathbf{1 9}$ & 12 & $\mathbf{4 0}$ & 11 & & \\
\cline { 1 - 3 } $\mathbf{2 1}$ & 12 & $\mathbf{4 1}$ & 12 & & \\
\cline { 1 - 3 } & 12 & $\mathbf{4 2}$ & 9 & & \\
\cline { 1 - 3 } & 12 & $\mathbf{4 3}$ & 8 & & \\
\end{tabular}

Tabel 5.8 Rekapan Penilaian Tindakan Responden dalam penggunaan kondom

Tindakan wanita pekerja seks yang menjadi responden dalam penggunaan kondom terbanyak memiliki tindakan baik yaitu 40 orang (66,7\%) dan sisanya memiliki tindakan buruk yaitu 20 orang (33,3\%).

\begin{tabular}{|c|l|c|c|}
\hline No & \multicolumn{1}{|c|}{ Sikap } & Jumlah & Prosentase \\
\hline 1 & Baik & 40 & $66,7 \%$ \\
\hline 2 & Buruk & 20 & $33,3 \%$ \\
\hline & Total & $\mathbf{6 0}$ & $\mathbf{1 0 0 \%}$ \\
\hline
\end{tabular}

Tabel 5.9 Distribusi frekuensi kategori tindakan wanita pekerja seks di lokalisasi km 12 Palangka Raya dalam penggunaan kondom

\subsubsection{Analisis hubungan pengetahuan responden dengan sikap responden dalam mencegah HIV/AIDS menggunakan kondom}

Setelah dilakukan perhitungan silang antara pengetahuan responden dengan sikap responden dalam mencegah HIV/AIDS menggunakan kondom diperoleh hasil bahwa wanita pekerja seks dengan pengetahuan sedang sebanyak 42 orang (70\%) memiliki sikap sedang dalam menggunakan kondom, 1 orang $(1,7 \%)$ memiliki sikap buruk dan tidak ada yang memiliki sikap baik dalam menggunakan kondom (0\%). Responden dengan pengetahuan buruk sebanyak 7 orang (11,7\%) memiliki sikap sedang dalam menggunakan kondom, 5 orang (8,3\%) memiliki sikap buruk dan tidak ada yang memiliki sikap baik dalam menggunakan kondom (0\%). Responden dengan pengetahuan baik sebanyak 5 orang (8,3\%) memiliki sikap sedang dalam menggunakan kondom dan tidak ada yang memiliki sikap baik dan sikap buruk dalam menggunakan kondom (0\%). Berdasarkan uji chi-square dengan tingkat kemaknaan 95\% (nilai chi-square hitung > chi-square tabel) didapatkan nilai 16,740 $>$ 5,991 sehingga Ho ditolak yaitu terdapat perbedaan persentase yang bermakna antara wanita pekerja seks berpengetahuan baik tentang HIV/AIDS dengan wanita pekerja seks berpengetahuan buruk dalam menentukan sikap untuk menggunakan kondom atau terdapat hubungan antara pengetahuan wanita pekerja seks mengenai HIV/AIDS dengan sikap wanita pekerja seks dalammenggunakan kondom.

\begin{tabular}{|l|l|l|l|l|l|}
\hline No. & $\begin{array}{l}\text { Pengetahuan } \\
\text { responden ttg } \\
\text { HIV/AIDS dan } \\
\text { kondom }\end{array}$ & \multicolumn{2}{|l|}{ Sikap responden dalam penggunaan kondom } & \multirow{2}{*}{ Total } \\
\cline { 2 - 5 } & Sikap baik & Sikap sedang & Sikap buruk & \\
\hline 1 & Pengetahuan baik & $0(0 \%)$ & $5(8,3 \%)$ & $0(0 \%)$ & $5(8,3 \%)$ \\
\hline
\end{tabular}




\begin{tabular}{|l|l|r|r|r|r|}
\hline 2 & Pengetahuan sedang & $0(0 \%)$ & $42(70 \%)$ & $1(1,7 \%)$ & $43(71,7 \%)$ \\
\hline 3 & Pengetahuan buruk & $0(0 \%)$ & $7(11,7 \%)$ & $5(8,3 \%)$ & $12(20 \%)$ \\
\hline Total & $0(0 \%)$ & $54(90 \%)$ & $6(10 \%)$ & $60(100,0 \%)$ \\
\hline
\end{tabular}

(hasil uji chi-square, nilai chi-square hitung > chi-square tabel, diperoleh nilai 16,740 > $5,991)$

Tabel 6.0 Distribusi frekuensi hubungan antara pengetahuan wanita pekerja seks mengenai HIV/AIDS dan kondom dengan sikap wanita pekerja seks dalam mencegah HIV/AIDS menggunakan kondom di lokalisasi km 12 Palangka Raya

\subsubsection{Analisis hubungan pengetahuan responden dengan tindakan responden dalam mencegah HIV/AIDS menggunakan kondom}

Setelah dilakukan perhitungan silang antara pengetahuan responden dengan tindakan responden dalam mencegah HIV/AIDS menggunakan kondom diperoleh hasil bahwa wanita pekerja seks dengan pengetahuan sedang sebanyak 33 orang (55\%) memiliki tindakan baik dalam menggunakan kondom dan 10 orang (16,7\%) memiliki tindakan baik dalam menggunakan kondom. Responden dengan pengetahuan buruk sebanyak 9 orang (15\%) memiliki tindakan buruk dalam menggunakan kondom dan 3 orang (5\%) memiliki tindakan baik dalam menggunakan kondom. Responden dengan pengetahuan baik sebanyak 4 orang (6,7\%) memiliki tindakan baik dalam menggunakan kondom dan 1 orang (1,6\%) memiliki tindakan buruk dalam menggunakan kondom. Berdasarkan uji chisquare dengan tingkat kemaknaan 95\% (nilai chi-square hitung > chi-square tabel) didapatkan nilai 11,740 > 5,991 sehingga Ho ditolak yaitu terdapat perbedaan persentase yang bermakna antara wanita pekerja seks berpengetahuan baik tentang HIV/AIDS dengan wanita pekerja seks berpengetahuan buruk dalam menentukan tindakan untuk menggunakan kondom atau terdapat hubungan antara pengetahuan wanita pekerja seks mengenai HIV/AIDS dengan tindakan wanita pekerja seks dalam menggunakan kondom.

\begin{tabular}{|l|l|r|r|r|}
\hline No. & $\begin{array}{l}\text { Pengetahuan responden } \\
\text { ttg HIV/AIDS dan } \\
\text { kondom }\end{array}$ & \multicolumn{2}{|l|}{$\begin{array}{l}\text { Tindakan responden dalam } \\
\text { penggunaan kondom }\end{array}$} & \multirow{2}{*}{ Total } \\
\cline { 3 - 4 } & $\begin{array}{l}\text { Tindakan baik } \\
\text { Tindakan Buruk }\end{array}$ & \\
\hline 1 & Pengetahuan baik & $4(6,7 \%)$ & $1(1,6 \%)$ & $5(8,3 \%)$ \\
\hline 2 & Pengetahuan sedang & $33(55 \%)$ & $10(16,7 \%)$ & $43(71,7 \%)$ \\
\hline 3 & Pengetahuan buruk & $3(5 \%)$ & $9(15 \%)$ & $12(20 \%)$ \\
\hline Total & & $40(66,7 \%)$ & $20(33,3 \%)$ & $60(100,0 \%)$ \\
\hline
\end{tabular}

(hasil uji chi-square, nilai chi-square hitung > chi-square tabel, diperoleh nilai 11,740 > 5,991)

Tabel 6.1 Distribusi frekuensi hubungan antara pengetahuan wanita pekerja seks mengenai HIV/AIDS dan kondom dengan tindakan wanita pekerja seks dalam mencegah HIV/AIDS menggunakan kondom di lokalisasi km 12 Palangka Raya

\section{B. Pembahasan}

Perilaku merupakan hasil segala macam pengalaman serta interaksi manusia dengan lingkungan yang terwujud dalam bentuk pengetahuan dan tindakan manusia sebagai makhluk hidup yang dilengkapi dengan akal yang berfungsi untuk mengontrol dan mengendalikan perilaku agar sesuai dengan yang diharapkan. Perilaku dapat dikelompokkan menjadi tiga jenis sebagai berikut :

- Perilaku dalam bentuk pengetahuan yaitu mengetahui situasi atau rangsangan dari luar. 
- Perilaku dalam bentuk sikap yaitu tanggapan batin terhadap keadaan atau rangsangan dari luar diri si subyek yang menimbulkan perasaan suka atau tidak suka.

- Perilaku dalam bentuk tindakan/praktik yang sudah nyata yaitu perbuatan terhadap situasi atau rangsangan dari luar.(Notoatmodjo,2003).

\subsubsection{Pengetahuan responden mengenai HIV/AIDS}

Hasil penelitian menunjukkan pengetahuan wanita pekerja seks yang menjadi responden mengenai HIV/AIDS dan kondom sebanyak 43 orang (71,7 \%) memiliki pengetahuan sedang, 12 orang (20\%) memiliki pengetahuan buruk dan sisanya 5 orang (8,3\%) memiliki pengetahuan baik. Pengetahuan merupakan hasil dari tahu yang terjadi setelah orang melakukan penginderaan terhadap suatu obyek tertentu. Pengetahuan kognitif merupakan domain yang sangat penting untuk terbentuknya tindakan seseorang. Pengetahuan yang ada tersebut bertujuan untuk menjawab permasalahan kehidupan manusia yang dihadapi sehari- hari dan digunakan untuk kemudahan-kemudahan tertentu. Pengetahuan dapat diperoleh melalui melihat, mendengar atau mengalami suatu kejadian yang nyata selain itu dapat pula diperoleh melalui belajar di bangku pendidikan baik bersifat formal maupun informal. Pengetahuan wanita pekerja seks yang masih sedikit berada dalam kategori baik bisa disebabkan berbagai hal yaitu rendahnya tingkat pendidikan yang pernah ditempuh wanita pekerja seks dan kurangnya penyuluhan dan sosialisasi mengenai HIV/AIDS kepada wanita pekerja seks sebagai pelaku utama dalam prostitusi.

\subsubsection{Sikap Responden dalam menggunakan kondom}

Hasil penelitian menunjukkan sikap wanita pekerja seks yang menjadi responden dalam menggunakan kondom untuk mencegah HIV/AIDS terbanyak memiliki sikap sedang yaitu 54 orang (90\%), sikap buruk sebanyak 6 orang (10\%) dan tidak ada (0\%) wanita pekerja seks yang memiliki sikap baik dalam menggunakan kondom. Sikap merupakan reaksi atau respon yang masih tertutup dari seseorang terhadap suatu stimulus atau obyek. Sikap sering diperoleh dari pengalaman sendiri atau dari orang lain yang paling dekat. (Notoatmodjo,2003). Sikap terdiri dari berbagai tingkatan yaitu : menerima, merespon, menghargai dan bertanggung jawab. Sikap yang utuh dipengaruhi oleh pengetahuan, keyakinan dan emosi seseorang. Sikap wanita pekerja seks yang tidak ada masuk dalam kategori baik dapat disebabkan karena pengetahuannya masih kurang mengenai HIV/AIDS yang dapat dicegah dengan menggunakan kondom. Sikap merupakan faktor salah satu faktor predisposisi untuk terbentuknya perilaku baru. Untuk mendapatkan sikap wanita pekerja seks yang baik dapat dilakukan dengan mengadakan pelatihan tentang penggunaan kondom secara rutin.

\subsubsection{Tindakan responden dalam menggunakan kondom}

Hasil penelitian menunjukkan tindakan wanita pekerja seks yang menjadi responden dalam penggunaan kondom terbanyak memiliki tindakan baik yaitu 40 orang $(66,7 \%)$ dan sisanya memiliki tindakan buruk yaitu 20 orang (33,3\%). Tindakan merupakan salah satu dari tiga perilaku berbentuk perbuatan terhadap situasi atau rangsangan dari luar. Tindakan seseorang berkaitan dengan sikap dan keyakinan yang dimiliki terhadap suatu obyek dalam hal ini mengenai penggunaan kondom. Tindakan wanita pekerja seks terbesar berada dalam kategori baik hal ini menunjukkan wanita pekerja seks mempunyai keyakinan yang positif mengenai penggunaan kondom sehingga menimbulkan tindakan yang positif pula. Keyakinan yang positif ini dapat terbentuk melalui informasi dan komunikasi yang berkesinambungan dan terus menerus dari berbagai sumber. 


\subsubsection{Hubungan pengetahuan responden dengan sikap responden dalam penggunaan kondom} Berdasarkan uji chi-square dengan tingkat kemaknaan 95\% (nilai chi-square hitung > chi-square tabel) didapatkan nilai 16,740 > 5,991 sehingga Ho ditolak yaitu terdapat perbedaan persentase yang bermakna antara wanita pekerja seks berpengetahuan baik tentang HIV/AIDS dengan wanita pekerja seks berpengetahuan buruk dalam menentukan sikap untuk menggunakan kondom atau terdapat hubungan antara pengetahuan wanita pekerja seks mengenai HIV/AIDS dengan sikap wanita pekerja seks dalam menggunakan kondom. Hal ini sesuai dengan teori notoatmodjo mengenai sikap yang utuh dipengaruhi oleh pengetahuan, keyakinan dan emosi seseorang. Pengetahuan seseorang yang buruk akan membuat sikap seseorang juga buruk dalam hal ini mengenai pencegahan HIV/AIDS dengan menggunakan kondom. Untuk itu perlu diberikan stimulus berupa informasi mengenai HIV/AIDS dan penggunaan kondom agar terbentuk pengetahuan dan keyakinan yang positif sehingga nantinya dapat merubah sikap wanita pekerja seksmenjadi positif dalammenggunakan kondom.

\subsubsection{Hubungan pengetahuan respondendengantindakanrespondendalampenggunaankondom}

Berdasarkan uji chi-square dengan tingkat kemaknaan 95\% (nilai chi-square hitung > chi-square tabel) didapatkan nilai 11,740 > 5,991 sehingga Ho ditolak yaitu terdapat perbedaan persentase yang bermakna antara wanita pekerja seks berpengetahuan baik tentang HIV/AIDS dengan wanita pekerja seks berpengetahuan buruk dalam menentukan tindakan untuk menggunakan kondom atau terdapat hubungan antara pengetahuan wanita pekerja seks mengenai HIV/AIDS dengan tindakan wanita pekerja seks dalam menggunakan kondom. Pengetahuan kognitif merupakan domain yang sangat penting untuk terbentuknya tindakan seseorang. Dalam hal ini terbukti pengetahuan wanita pekerja seks yang baik mengenai HIV/AIDS dan kondom akan membentuk tindakan yang baik pula dari wanita pekerja seks untuk menggunakan kondom. Pengetahuan ini dapat diperoleh melalui penyuluhan dan sosialisasi yang rutin dan berkesinambungan kepada wanita pekerja seks untuk memberikan informasi sekaligus komunikasi mengenai HIV/AIDS dan kondom. Melalui pengetahuan yang dimiliki dapat membentuk keyakinan dan sikap yang positif sehingga mendorong wanita pekerja seks memiliki tindakan yang positif pula dalam menggunakan kondom.

\section{F. Kesimpulan dan Saran}

\subsection{Kesimpulan}

Dari hasil penelitian yang telah dilakukan pada wanita pekerja seks di lokalisasi km 12 Palangka Raya dapat disimpulkan :

- Persentase pengetahuan wanita pekerja seks yang menjadi responden mengenai HIV/AIDS dan kondom sebanyak 43 orang (71,7 \%) memiliki pengetahuan sedang, 12 orang (20\%) memiliki pengetahuan buruk dan sisanya 5 orang $(8,3 \%)$ memiliki pengetahuan baik.

- Persentase sikap wanita pekerja seks yang menjadi responden dalam menggunakan kondom untuk mencegah HIV/AIDS terbanyak memiliki sikap sedang yaitu 54 orang (90\%), sikap buruk sebanyak 6 orang $(10 \%)$ dan tidak ada $(0 \%)$ wanita pekerja seks yang memiliki sikap baik dalam menggunakan kondom.

- Persentase tindakan wanita pekerja seks yang menjadi responden dalam penggunaan kondom terbanyak memiliki tindakan baik yaitu 40 orang $(66,7 \%)$ dan sisanya memiliki tindakan buruk yaitu 20 orang (33,3\%).

- Hasil uji chi-square dengan tingkat kemaknaan 95\% (nilai chi-square hitung > chisquare tabel) didapatkan nilai 16,740 > 5,991 sehingga Ho ditolak yaitu terdapat perbedaan persentase yang bermakna antara wanita pekerja seks berpengetahuan baik tentang HIV/AIDS dengan wanita pekerja seks 
berpengetahuan buruk dalam menentukan sikap untuk menggunakan kondom atau terdapat hubungan antara pengetahuan wanita pekerja seks mengenai HIV/AIDS dengan sikap wanita pekerja seks dalammenggunakan kondom.

- Hasil uji chi-square dengan tingkat kemaknaan 95\% (nilai chi-square hitung > chisquare tabel) didapatkan nilai 11,740 > 5,991 sehingga Ho ditolak yaitu terdapat perbedaan persentase yang bermakna antara wanita pekerja seks berpengetahuan baik tentang HIV/AIDS dengan wanita pekerja seks berpengetahuan buruk dalam menentukan tindakan untuk menggunakan kondom atau terdapat hubungan antara pengetahuan wanita pekerja seks mengenai HIV/AIDS dengan tindakan wanita pekerja seksdalammenggunakan kondom.

\subsection{Saran}

Bagi pengelola lokalisasi km 12 Palangka Raya :

- Mengadakan pembinaan kepada wanita pekerja seks dengan sosialisasi ataupun penyuluhan melalui dinas kesehatan kota Palangka Raya mengenai HIV/AIDS dan kondom.

- Mengadakan pelatihan penggunaan kondom secara rutin.

- Menyediakan kondom bagi wanita pekerja seks.

- Membuat regulasi untuk mendisiplinkan penggunaan kondom dengan memberikan sanksi bagi wanita pekerja seks maupun pelanggan yang tidak bersedia menggunakan kondom.

\section{Bagi wanita pekerja seks :}

- Meningkatkan pengetahuannya secara pribadi dengan aktif bertukar informasi sesama wanita pekerja seks mengenai HIV/AIDS dan penggunaan kondom.

- Rutin memeriksakan kesehatan terutama apabila mengalami salah satu tanda dan gejala dari HIV/AIDS untuk mendapatkan pengobatan dini dan mencegah penyebaran HIV/AIDS.

- Disiplin untuk menggunakan kondom selama melayani pelanggan.

\section{Referensi}

1. Arikunto S, 2006. Prosedur Penelitian Suatu Pendekatan Praktik. PT Rineka Cipta. Jakarta

2. BKKBN.2005. Peningkatan Partisipasi Pria dalam KB \& KR.Jakarta.

3. Depkes RI.2001. Profil Kesehatan Indonesia Tahun 2001.Jakarta.

4. Depkes RI. 2007. Riset Kesehatan Dasar. Badan Penelitian dan Pengembangan Kesehatan. Jakarta.

5. Depkes RI. 2010. Riset Kesehatan Dasar. Badan Penelitian dan Pengembangan Kesehatan. Jakarta.

6. Ditjen PPM \& PL Kementerian Kesehatan. 2011. Statistik Kasus HIV/AIDS di Indonesia. Jakarta: Kementerian Kesehatan.

7. Fadhali Andi, et al. 2012. Faktor yang Berhubungan dengan Pencegahan HIV dan AIDS di, (http://repository.unhas.ac.id/bitstream/handle, diakses 30 Mei 2013).

8. Hadi TS. 2004. Faktor-faktor yang Mempengaruhi Praktik Negosiasi Penggunaan Kondom Untuk Mencegah Ims dan HIV/AIDS pada WPS di Resosialisasi Argorejo Kelurahan Kalibanteng Kulon Kecamatan Semarang Barat Kota Semarang. (Online), (http://eprints.undip.ac.id/14514/1/2004MPK3579.pdf, diakses 1 Juni 2013).

9. Juliastika, et al. 2011. Hubungan Pengetahuan tentang HIV/AIDS dengan Sikap dan Tindakan Penggunaan Kondom Pria pada Wanita Pekerja Seks di Kota Manado. 
(Online),

5, diakses 30 Mei 2013).

(http://ejournal.unsrat.ac.id/index.php/kesmas/article/download/79/7

10. Kaltengpos. 2013. Jumlah PSK terbanyak ada di Kotim.(Online), (http: www.kaltengpos.co.id, di akses 16 Juni 2013).

11. Kenderweis, Yustina I. 2010. Kemampuan Tawar Pekerja Seks Komersial dalam Penggunaan Kondom Untuk Mencegah Penularan HIV/AIDS di Jalan Lintas Sumatera Kabupaten Langkat Propinsi Sumatera Utara, Berita Kedokteran Masyarakat. (Online), Volume $26 \quad$ No.1 (http://beritakedokteran- masyarakat.org/index.php/BKM/article/view/213/110, diakses 25 Januari 2013).

12. Manuaba, dkk. 2010. Ilmu Kebidanan, Penyakit Kandungan, \& Keluarga Berencana untuk Pendidikan Bidan edisi 2. Jakarta : EGC.

13. Notoatmodjo, S. 2003. Pendidikan dan Perilaku Kesehatan. PT Rineka Cipta. Jakarta.

14. Price Sylvia A, Lorraine Wilson.2006. Patofisiologi. Volume 1. Jakarta : EGC.

15. Siregar FA. 2004. Pengenalan dan Pencegahan AIDS.

(Online) (http://library.usu.ac.id/download/fkm/fkm-fazidah4.pdf, diakses $30 \mathrm{Mei}$ 2013).

16. Spritia. 2009. (Online) (http://spiritia.or.id/Stats/Statistic.php, diakses 25 Januari 2013).

17. Syaifudin. 2003. Buku Panduan Praktis Pelayanan Kontrasepsi. Yayasan Bina Pustaka Sarwono Prawirohardjo. Jakarta.

18. UNAIDS, 2009. AIDS Epidemic Update, Geneva, UNAIDS. 